\title{
5-hydroxytryptamine has an endothelium- derived hyperpolarizing factor-like effect on coronary flow in isolated rat hearts
}

\author{
Ching-Chia Chang Chien and Ming-Jai Su*
}

\begin{abstract}
Background: 5-hydroxytryptamine (5-HT)-induced coronary artery responses have both vasoconstriction and vasorelaxation components. The vasoconstrictive effects of 5-HT have been well studied while the mechanism(s) of how 5-HT causes relaxation of coronary arteries has been less investigated. In isolated rat hearts, 5-HT-induced coronary flow increases are partially resistant to the nitric oxide synthase inhibitor N $\omega$-Nitro-L-arginine methyl ester (L-NAME) and are blocked by $5-\mathrm{HT}_{7}$ receptor antagonists. In the present study, we investigated the role of 5-HT 7 receptor in 5-HT-induced coronary flow increases in isolated rat hearts in the absence of L-NAME, and we also evaluated the involvement of endothelium-derived hyperpolarizing factor (EDHF) in 5-HT-induced coronary flow increases in L-NAME-treated hearts with the inhibitors of arachidonic acid metabolism and the blockers of $\mathrm{Ca}^{2+}$-activated $\mathrm{K}^{+}$channels.

Results: In isolated rat hearts, $5-\mathrm{HT}$ and the $5-\mathrm{HT}_{7}$ receptor agonist 5-carboxamidotryptamine induced coronary flow increases, and both of these effects were blocked by the selective $5-\mathrm{HT}_{7}$ receptor antagonist SB269970; in SB269970-treated hearts, 5-HT induced coronary flow decreases, which effect was blocked by the 5-HT $2 \mathrm{~A}$ receptor blocker R96544. In L-NAME-treated hearts, 5-HT-induced coronary flow increases were blocked by the phospholipase $\mathrm{A}_{2}$ inhibitor quinacrine and the cytochrome P450 inhibitor SKF525A, but were not inhibited by the cyclooxygenase inhibitor indomethacin. As to the effects of the $\mathrm{Ca}^{2+}$-activated $\mathrm{K}^{+}$channel blockers, 5 -HT-induced coronary flow increases in L-NAME-treated hearts were inhibited by TRAM-34 (intermediate-conductance $\mathrm{Ca}^{2+}$-activated $\mathrm{K}^{+}$channel blocker) and UCL1684 (small-conductance $\mathrm{Ca}^{2+}$-activated $\mathrm{K}^{+}$channel blocker), but effects of the large-conductance $\mathrm{Ca}^{2+}$-activated $\mathrm{K}^{+}$channel blockers on $5-\mathrm{HT}$-induced coronary flow increases were various: penitrem $\mathrm{A}$ and paxilline did not significantly affect 5-HT-induced coronary flow responses while tetraethylammonium suppressed the coronary flow increases elicited by 5-HT.
\end{abstract}

Conclusion: In the present study, we found that 5-HT-induced coronary flow increases are mediated by the activation of $5-\mathrm{HT}_{7}$ receptor in rat hearts in the absence of L-NAME. Metabolites of cytochrome P450s, small-conductance $\mathrm{Ca}^{2+}$-activated $\mathrm{K}^{+}$channel, and intermediate-conductance $\mathrm{Ca}^{2+}$-activated $\mathrm{K}^{+}$channel are involved in 5 -HT-induced coronary flow increases in L-NAME-treated hearts, which resemble the mechanisms of EDHF-induced vasorelaxation. The role of large-conductance $\mathrm{Ca}^{2+}$-activated $\mathrm{K}^{+}$channel in 5-HT-induced coronary flow increases in L-NAME-treated hearts needs further investigation.

Keywords: Serotonin, 5-HT, Nitric oxide, NO, Endothelium-derived hyperpolarization factor, EDHF, Coronary flow, Rat, NO-independent

\footnotetext{
* Correspondence: mingja@ntu.edu.tw

Institute of Pharmacology, College of Medicine, National Taiwan University,

11F No.1 Sec.1, Ren-ai Rd, Taipei 10051, Taiwan
}

\section{() Biomed Central}

(c) 2015 Chang Chien and Su. This is an Open Access article distributed under the terms of the Creative Commons Attribution License (http://creativecommons.org/licenses/by/4.0), which permits unrestricted use, distribution, and reproduction in any medium, provided the original work is properly credited. The Creative Commons Public Domain Dedication waiver (http:// creativecommons.org/publicdomain/zero/1.0/) applies to the data made available in this article, unless otherwise stated. 


\section{Background}

5-hydroxytryptamine (5-HT) has both vasoconstrictive and vasodilating effects on coronary arteries [1, 2]; injecting low doses of 5-HT into normal human coronary arteries induces vascular dilations, but at high doses 5-HT injections cause vasoconstrictions [1]. The vasoconstrictive effect of 5-HT on coronary arteries is mostly mediated by $5-\mathrm{HT}_{2 \mathrm{~A}}$ receptor, and to a lesser extent by the activation of $5-\mathrm{HT}_{1 \mathrm{~B}}$ receptor $[3,4]$. The knowledge about the vasoconstrictive effects of 5 -HT on coronary arteries has been applied to develop treatments of coronary artery diseases [3].

$5-\mathrm{HT}_{7}$ receptor is the latest identified subtype of $5-\mathrm{HT}$ receptors [5]. It couples to Gs protein and induces cAMP accumulation when activated [6], and in rat glomerulosa cells the activation of $5-\mathrm{HT}_{7}$ receptor increases calcium influx via $\mathrm{T}$-type $\mathrm{Ca}^{2+}$ channels by raising adenylyl cyclase activity [7]. Activation of $5-\mathrm{HT}_{7}$ receptor has been reported mediating 5 -HT-induced relaxation in isolated dog coronary arteries [8] and 5-HT-induced coronary flow increases in $\mathrm{N \omega}$-Nitro-L-arginine methyl ester hydrochloride (L-NAME)-treated rat hearts [9]. The functional role of $5-\mathrm{HT}_{7}$ receptor in human coronary arteries has not been reported, but the mRNA expression of $5-\mathrm{HT}_{7}$ receptor in human coronary vasculature has been identified [4].

The mechanism(s) of how 5-HT mediates coronary artery relaxation remains controversial. In dog coronary arteries, both endothelium-dependent [10] and endotheliumindependent [8] vasodilating effects of 5-HT have been reported. In rat, coronary flow increases/coronary artery relaxation effect of 5 - $\mathrm{HT}$ has been proposed to be endothelium-dependent $[11,12]$ and nitric oxide (NO)dependent [13]; however, prostacyclin $\left(\mathrm{PGI}_{2}\right)$-dependent [14] and nitric oxide synthase (NOS) inhibitor-resistant [9] components of this effect have also been reported.

Endothelium-derived hyperpolarizing factor (EDHF) is a putative factor that mediates endothelium-dependent vasorelaxation $[15,16]$. It induces vasodilation by hyperpolarizing the membrane potential of smooth muscle cells, which effect consequently prevents the activation of $\mathrm{Ca}^{2+}$ channels and reduces $\mathrm{Ca}^{2+}$ influx [17]. Although the mechanism(s) and the end effector(s) of EDHFinduced vasorelaxation remain controversial [18], activations of $\mathrm{Ca}^{2+}$-activated $\mathrm{K}^{+}$channels by arachidonic acid metabolites synthesized by endothelial lipoxygenases (LOXs) and cytochrome P450s are known to be involved in EDHF-mediated vascular responses $[18,19]$.

In our previous study, we found that 5-HT-induced coronary flow increases in isolated rat hearts have a LNAME-resistant component [9], and the 5-HT-induced coronary flow increases in L-NAME-treated hearts are blocked by $5-\mathrm{HT}_{7}$ receptor antagonists [9]; however, the role of $5-\mathrm{HT}_{7}$ receptor activation in the $\mathrm{NO}$-dependent component of 5-HT-induced coronary flow increases was left unevaluated, and the mechanism(s) of the LNAME-resistant component of the coronary flowincreasing effect was not studied. In the present study, we investigated the role of $5-\mathrm{HT}_{7}$ receptor in 5 -HTinduced coronary flow increases in the absence of LNAME in isolated rat hearts by using selective 5-HT receptor agonist and antagonist, and we also evaluated the role of EDHF in 5-HT-induced coronary flow increases by testing effects of blockers of arachidonic acid metabolism $[18,20]$ and $\mathrm{Ca}^{2+}$-activated $\mathrm{K}^{+}$channels [16] on 5-HT-induced coronary flow increases in L-NAMEtreated hearts.

\section{Methods \\ Animals}

Adult male Sprague Dawley rats aged 2-3 months (weighting 250-350 g) were purchased from BioLasco Co. (Yilan, Taiwan). Animals were kept in the Laboratory Animal Center of National Taiwan University (Taipei, Taiwan) until the day of experiment. Rats were given ad libitum access to water and food. All animal procedures were performed according to the Guide for the Care and Use of Laboratory Animals of the National Institutes of Health, and followed the guidelines of the Animal Welfare Act. The animal studies were approved with a certificate number 20110073 by the Institutional Animal Care and Use Committee of the College of Medicine, National Taiwan University (Taipei, Taiwan).

\section{Chemicals and solution}

5-HT, adenosine, histamine, indomethacin, tetraethylammonium chloride (TEA), L-NAME, and dimethyl sulfoxide (DMSO) were purchased form Sigma-Aldrich (St. Louis, Missouri, USA). SB269970, R96544, 5-carboxamindotryptamine (5-CT), TRAM-34, and UCL1684 were purchased from Tocris Bioscience (Bristol, United Kingdom). Quinacrine, penitrem A, paxilline, and SKF525A were purchased from Cayman Chemical Co. (Ann Arbor, Michigan, USA).

The perfusion solution used in the present study was modified Tyrode's solution (in $\mathrm{mM}$ ): $119.7 \mathrm{NaCl}, 23.8$ $\mathrm{NaHCO}_{3}$, 5.6 Glucose, $1.2 \mathrm{CaCl}_{2}, 1.1 \mathrm{MgCl}_{2}, 0.3 \mathrm{NaH}_{2} \mathrm{PO}_{4}$, and $5.0 \mathrm{KCl}$. In the experiments testing the effects of the inhibitors of arachidonic acid metabolism and the blockers of $\mathrm{Ca}^{2+}$-activated $\mathrm{K}^{+}$channels on 5 -HT-induced coronary flow increases, L-NAME $10 \mu \mathrm{M}$ was added to the perfusion solution and existed throughout the experiments.

\section{Preparation of isolated perfused rat hearts}

Rats were intraperitoneally injected with pentobarbital $50 \mathrm{mg} / \mathrm{kg}$ and heparin $800 \mathrm{IU} / \mathrm{kg}$. $15 \mathrm{~min}$ later, rats were killed by cervical dislocation and hearts were quickly 
removed and mounted on the Langendorff apparatus (ADInstruments, Castle Hill, Australia).

Hearts were perfused with modified Tyrode's solution at constant pressure $(70 \mathrm{mmHg})$. The perfusion solution was kept at $37{ }^{\circ} \mathrm{C}$ and well gassed with carbogen $\left(\mathrm{O}_{2} 95 \%\right.$ and $\mathrm{CO}_{2} 5 \%$ mixture).

Tissue around the sinoatrial node was trimmed to slow down the spontaneous heart rate. Stimulating electrodes were placed on the left atrium, and recording electrodes were attached to the apex to record electric cardiogram (EKG). Hearts were constantly paced at 250 b.p.m throughout experiment with stimulations generated by a stimulator with stimulation length of $2 \mathrm{~ms}$ and an interval of $240 \mathrm{~ms}$. Hearts were then left to stabilize for $30 \mathrm{~min}$ before subjected to experiment. The perfusion pressure, coronary flow, and EKG were demonstrated and recorded continuously on computer using PowerLab program (ADInstruments, Castle Hill, Australia).

Effects of the 5-HT receptor antagonists on 5-HT-induced coronary flow responses in isolated perfused hearts

Hearts were prepared as described above. After $30 \mathrm{~min}$ stabilization, hearts were treated with vehicle, SB269970 $0.3 \mu \mathrm{M}$ (a selective $5-\mathrm{HT}_{7}$ receptor antagonist [21]), or SB269970 $0.3 \mu \mathrm{M}+\mathrm{R} 965440.3 \mu \mathrm{M}$ (a selective $5-\mathrm{HT}_{2 \mathrm{~A}}$ receptor antagonist [22]) for $4 \mathrm{~min}$; 5-HT 0.3 and $1 \mu \mathrm{M}$ were then added into perfusion solution cumulatively to test effects of these antagonist(s) on 5-HT-induced coronary responses. These concentrations of 5-HT were chosen on the basis of our preliminary observations, in which 5HT-induced coronary flow responses are not stable at concentrations higher than $1 \mu \mathrm{M}$ (data not shown).

5-HT-induced coronary flow increases have been reported as NO-dependent [12], so in the antagonist(s)treated groups we added adenosine $0.1 \mu \mathrm{M}$, which is also an $\mathrm{NO}$ /endothelium-dependent [23] vasodilator of rat coronary arteries, to test the viability of endothelium and the activity of NOS at the end of experiments. The protocol is summarized in Fig. 1a.

\section{Effect of SB269970 on 5-CT-induced coronary flow responses in isolated perfused hearts}

Hearts were prepared as described above. After stabilization, hearts were treated with vehicle (DMSO $1 \mu \mathrm{l} / \mathrm{dl}$ ) or SB269970 $0.3 \mu \mathrm{M}$ for $4 \mathrm{~min}$, and then $10 \mathrm{nM}$ and $30 \mathrm{nM}$ of $5-\mathrm{CT}$, a selective and potent $5-\mathrm{HT}_{1 \mathrm{~B} / 7}$ receptor agonist [24], were added into the perfusion solution in a doseaccumulative manner in the presence of vehicle or SB269970 to test the effect of the $5-\mathrm{HT}_{7}$ receptor antagonist on 5-CT-induced coronary flow increases. Adenosine $0.1 \mu \mathrm{M}$ was added into the perfusion solution at the end of experiment to test the viability of endothelium and the activity of NOS if 5-CT failed to elicit coronary flow increase in the presence of SB269970. The protocol is summarized in Fig. 1b.

\section{Effects of the inhibitors of arachidonic acid metabolism on 5-HT-induced coronary flow increases in L-NAME- treated rat hearts}

Isolated perfused hearts were prepared and the experiments were performed with L-NAME-containing perfusion solution as mentioned above.

After 30 min stabilization, hearts were treated with vehicle (DMSO $10 \mu \mathrm{l} / \mathrm{dl}$ ) for $10 \mathrm{~min}$, and coronary flow responses to 5 -HT 0.3 and $1 \mu \mathrm{M}$ were tested in the presence of vehicle. After the tests of coronary flow responses to 5HT were established, each heart was perfused with fresh LNAME-containing solution for $20 \mathrm{~min}$ to remove the effect of 5-HT and re-stabilize. Hearts were treated with $1 \mu \mathrm{M}$ quinacrine (phospholipase $\mathrm{A}_{2}\left(\mathrm{PLA}_{2}\right.$ ) inhibitor [15]), $3 \mu \mathrm{M}$ SKF525A (cytochrome P450s inhibitor [25]), or $10 \mu \mathrm{M}$ indomethacin (cyclooxygenase (COX) inhibitor [26]) for $10 \mathrm{~min}$, respectively, and then coronary flow responses to 5-HT were tested again in the presence of these treatments. Histamine is an endothelium-dependent vasodilator of rat coronary arteries [27, 28], which relaxes smooth muscle in a NO-independent manner [29], so we added histamine $10 \mu \mathrm{M}$ to test the viability of the coronary arteries at the end of experiments if 5-HT failed to elicit coronary flow responses. The protocol is summarized in Fig. 1c.

\section{Effects of the $\mathrm{Ca}^{2+}$-activated $\mathrm{K}^{+}$channel blockers on 5-HT-induced coronary flow responses in L-NAME-treated hearts}

Hearts were prepared and perfused with L-NAME $10 \mu \mathrm{M}$ as described above. After $30 \mathrm{~min}$ equilibration, each heart was perfused with vehicle for $15 \mathrm{~min}$, and then coronary flow responses to $5-\mathrm{HT}$, at concentrations of 0.3 and $1 \mu \mathrm{M}$, were tested in the presence of vehicle. In the TRAM-34- and UCL1684-treated groups, DMSO $100 \mu \mathrm{l} / \mathrm{dl}$ was used as vehicle control in the control tests; in the penitrem A- and paxilline-treated groups, DMSO $10 \mu \mathrm{l} / \mathrm{dl}$ was used as vehicle control in the control tests. The vehicle of TEA was the perfusion solution, so we just perfused the hearts for $15 \mathrm{~min}$ as vehicle treatment. After the first serial of 5-HT tests, hearts were then perfused with fresh L-NAME-containing perfusion solution for $20 \mathrm{~min}$ to re-equilibrate. After re-equilibration, hearts were perfused with TRAM-34 $10 \mu \mathrm{M}$ (selective blocker of intermediate-conductance $\mathrm{Ca}^{2+}$-activated $\mathrm{K}^{+}$ channel [30]), UCL1684 $3 \mu \mathrm{M}$ (selective blocker of smallconductance $\mathrm{Ca}^{2+}$-activated $\mathrm{K}^{+}$channel [31]), penitrem A $1 \mu \mathrm{M}$ [32], paxilline $2 \mu \mathrm{M}$ [33] (both selective blockers of large-conductance $\mathrm{Ca}^{2+}$-activated $\mathrm{K}^{+}$channel), or TEA $300 \mu \mathrm{M}$ for $15 \mathrm{~min}$, and then coronary flow responses to 5 -HT 0.3 and $1 \mu \mathrm{M}$ were tested again in the presence of these treatments. At the end of each experiment, 


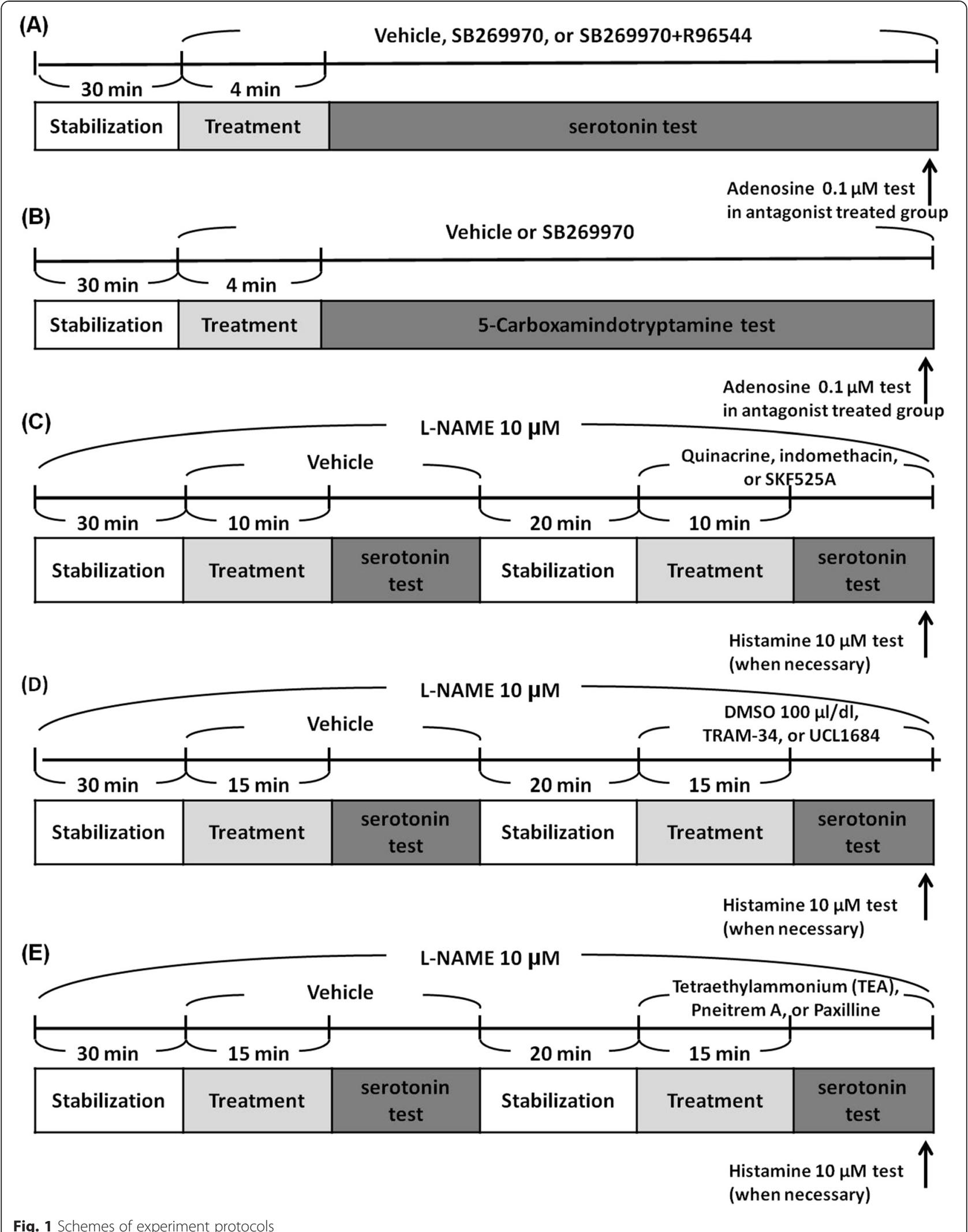

Fig. 1 Schemes of experiment protocols 
histamine $10 \mu \mathrm{M}$ was added into the perfusion solution to test the viability of coronary vasculature if 5-HT failed to elicit coronary flow increases in the presence of the treatments.

To validate the design of the experiments, we tested the effect of DMSO $100 \mu \mathrm{l} / \mathrm{dl}$, which was the vehicle we used in the UCL1684-treated and TRAM-34-treated groups and also the largest quantity of DMSO we used in this article, on 5-HT-elicited coronary flow responses by the same protocol used in testing the effects of $\mathrm{Ca}^{2+}$-activated $\mathrm{K}^{+}$ channel blockers. The protocols are summarized in Fig. $1 \mathrm{~d}$ and e.

\section{Statistic analysis}

Data were expressed as mean \pm SD. Intra-group analyses were performed with one-way ANOVA followed with Bonferroni post-tests. Inter-groups differences were analyzed by 2-ways ANOVA followed by Bonferroni post-tests. Variables from the adenosine tests and the histamine tests were not used when performing ANOVA and Bonferroni post-tests. $\mathrm{P}<0.05$ was considered to be statistically significant.

\section{Results}

Effects of the 5-HT receptor antagonists on 5-HT receptor agonist-induced coronary flow responses

Figure 2a shows the typical tracings of 5-HT-induced coronary flow responses in the presence of vehicle, SB269970, and combination of SB269970 and R96544.

As shown in Fig. 2b, 5-HT elicited coronary flow increases in the presence of vehicle in the control group $(\mathrm{P}<0.0001$ and $\mathrm{F}=19.11$, one-way ANOVA). Vehicle (DMSO $1 \mu \mathrm{l} / \mathrm{dl}$ ) did not significantly alter coronary flow in the control group (basal value $10.52 \pm 1.22 \mathrm{ml} / \mathrm{min}$ and after DMSO treatment $10.60 \pm 1.37 \mathrm{ml} / \mathrm{min}$ ); 5 -HT significantly increased coronary flow to $16.48 \pm 2.18(\mathrm{P}<0.01$ compared to treatment of vehicle) and $17.45 \pm 1.87 \mathrm{ml} /$ min $(\mathrm{P}<0.005$ compared to treatment of vehicle $)$ at concentrations of $0.3 \mu \mathrm{M}$ and $1 \mu \mathrm{M}$, respectively.

5-HT 0.3 and $1 \mu \mathrm{M}$ induced coronary flow decreases in the presence of SB269970 $0.3 \mu \mathrm{M}$ (Fig. 2b) $(\mathrm{n}=5 ; \mathrm{P}<$ 0.0001 and $F=14.33$, one-way ANOVA), which were significantly different from the responses in the control group ( $\mathrm{P}=0.0007$ and $\mathrm{F}=33.71,2$-ways ANOVA analyzed with the control group). Treatment with SB269970 $0.3 \mu \mathrm{M}$ did not significantly alter coronary flow (10.60 \pm $1.37 \mathrm{ml} / \mathrm{min}$ compared to basal value $10.50 \pm 1.22 \mathrm{ml} /$ $\mathrm{min})$; in the presence of SB269970 $0.3 \mu \mathrm{M}$, coronary flow decreased to $8.59 \pm 1.01 \mathrm{ml} / \mathrm{min}(\mathrm{P}<0.05$ compared to treatment $)$ and $7.82 \pm 0.68 \mathrm{ml} / \mathrm{min}(\mathrm{P}<0.005$ compared to treatment) after treatments of 5 -HT 0.3 and $1 \mu \mathrm{M}$, respectively. At the end of experiment, addition of adenosine $0.1 \mu \mathrm{M}$ caused an increase of coronary flow to $17.79 \pm$ $2.74 \mathrm{ml} / \mathrm{min}$ in the presence of SB269970 and 5-HT.
As shown in Fig. 2a and b, 5-HT failed to elicit coronary flow response at doses of 0.3 and $1 \mu \mathrm{M}$ in hearts treated with the combination of SB269970 $0.3 \mu \mathrm{M}$ and R96544 $0.3 \mu \mathrm{M}(\mathrm{n}=4 ; \mathrm{P}=0.345$ and $\mathrm{F}=1.22$, one-way ANOVA). Treatment of SB269970 $0.3 \mu \mathrm{M}+\mathrm{R} 96544$ $0.3 \mu \mathrm{M}$ slightly increased coronary flow to $11.15 \pm$ $0.83 \mathrm{ml} / \mathrm{min}$ from the basal value of $10.38 \pm 0.61 \mathrm{ml} /$ min. In the presence of SB269970 and R96544, coronary flow was not significantly altered by 5 -HT at concentrations of 0.3 and $1 \mu \mathrm{M}(11.07 \pm 0.58 \mathrm{ml} / \mathrm{min}$ and $11.07 \pm$ $0.54 \mathrm{ml} / \mathrm{min}$, respectively). At the end of experiment, addition of adenosine $0.1 \mu \mathrm{M}$ increased coronary flow to $15.96 \pm 1.94 \mathrm{ml} / \mathrm{min}$. The 5 -HT-induced coronary flow responses in SB269970+ R96544-treated group were significantly different from the SB269970-treated group ( $\mathrm{P}=0.0056$ and $\mathrm{F}=15.54$, analyzed by 2 -ways ANOVA with the SB269970 treated group) and the control group $(\mathrm{P}=0.0138$ and $\mathrm{F}=11.82$, 2-ways ANOVA analyzed with the control group).

$5-\mathrm{CT}$ is a potent $5-\mathrm{HT}_{1 \mathrm{~B} / 7}$ receptor agonist with low affinity to the $5-\mathrm{HT}_{2 \mathrm{~A}}$ receptor (Ki value $633-2700 \mathrm{nM}$ ) [24]. As shown in Fig. 2c, 5-CT elicited coronary flow increases in the control group $(\mathrm{n}=4 ; \mathrm{P}<0.0001$ and $\mathrm{F}=$ 18, one-way ANOVA), and 5-CT-elicited coronary flow increases were blocked by SB269970 $0.3 \mu \mathrm{M}(\mathrm{P}=0.0169$ and $\mathrm{F}=12.4,2$-ways ANOVA). Treatment with vehicle did not elicit significant coronary flow response in the control group $(10.83 \pm 1.09 \mathrm{ml} / \mathrm{min}$ compared to basal value $10.67 \pm 1.29 \mathrm{ml} / \mathrm{min}$ ); in the presence of vehicle, 5 CT $10 \mathrm{nM}$ induced a coronary flow increase to $16.54 \pm$ $2.74 \mathrm{ml} / \mathrm{min}$, and $5-\mathrm{CT} 30 \mathrm{nM}$ increased the coronary flow to $18.74 \pm 2.11 \mathrm{ml} / \mathrm{min}(\mathrm{P}<0.01$ and $\mathrm{P}<0.005 \mathrm{com}-$ pared to the vehicle treatment point, respectively). In the SB269970-treated group, 5-CT failed to elicit coronary flow response at 10 and $30 \mathrm{nM}(\mathrm{n}=3 ; \mathrm{P}=0.9573$ and $\mathrm{F}=$ 0.1008, one-way ANOVA). Treatment of SB269970 $0.3 \mu \mathrm{M}$ did not significantly alter coronary flow $(11.13 \pm$ $0.63 \mathrm{ml} / \mathrm{min}$ compared to the basal value $10.99 \pm 0.37 \mathrm{ml} /$ $\mathrm{min})$; however, it blocked the coronary flow-increasing effect of 5-CT. In the presence of SB269970 0.3 $\mu \mathrm{M}, 5-\mathrm{CT}$ at $10 \mathrm{nM}$ or $30 \mathrm{nM}$ did not elicited significant coronary flow alteration $(11.15 \pm 0.63 \mathrm{ml} / \mathrm{min}$ and $10.94 \pm 0.59 \mathrm{ml} /$ min, respectively). In the precence of SB269970 $0.3 \mu \mathrm{M}$ and 5-CT $30 \mathrm{nM}$, addition of adenosine $0.1 \mu \mathrm{M}$ increased coronary flow to $19.01 \pm 5.03 \mathrm{ml} / \mathrm{min}$ at the end of experiment.

\section{Effects of the inhibitors of arachidonic acid metabolism on 5-HT-induced coronary flow increases in L-NAME- treated hearts}

Quinacrine (Fig. 3a) significantly suppressed the 5-HTinduced coronary flow increases in L-NAME-treated rat hearts $(\mathrm{n}=5 ; \mathrm{P}=0.0032$ and $\mathrm{F}=16.73,2$-ways ANOVA). In the control test, 5-HT significantly increased coronary 
(A)
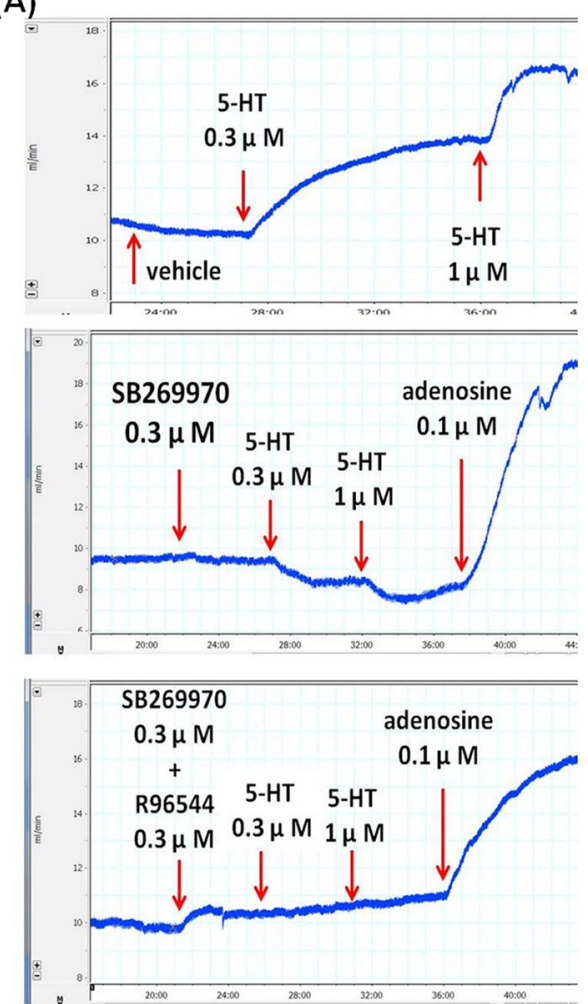

(B)

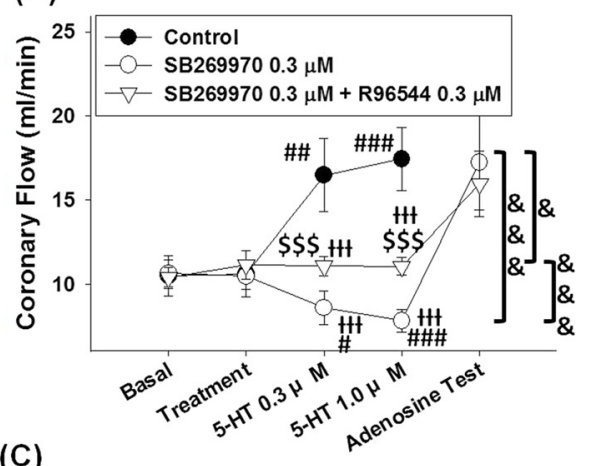

(C)

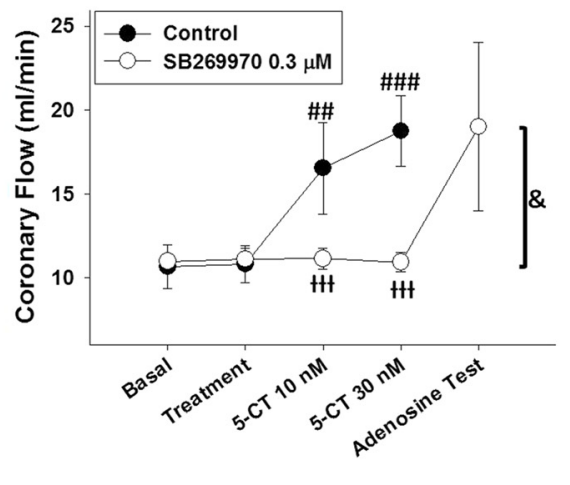

Fig. 2 Effects of the 5-HT receptor antagonists on 5-HT-induced coronary responses in isolated rat hearts. a Typical traces of 5-HT-induced coronary flow responses in the presence of vehicle, SB269970, or the combination of SB269970 and R96544. b In isolated rat heart, 5-HT induced coronary flow increases, but in 5-HT 7 receptor antagonist SB269970 $0.3 \mu \mathrm{M}$-treated hearts, 5-HT caused decreases in coronary flow. In hearts treated with SB269970 $0.3 \mu \mathrm{M}$ and the $5-\mathrm{HT}_{2 \mathrm{~A}}$ antagonist $\mathrm{R} 965440.3 \mu \mathrm{M}, 5-\mathrm{HT}$ did not elicit a coronary response. c The 5-HT 7 receptor agonist 5-CT elicited coronary flow increases, and this effect was blocked by SB269970 $0.3 \mu \mathrm{M}$. Data were expressed as the mean \pm SD. \#P $<0.05, \# \# P<0.01$, and \#\#\#P<0.005 compared to the treatment; HIP $<0.005$ compared to the control group (one-way ANOVA followed by Bonferroni post-test); $\$ \$ P<0.005$ compared to the SB269970-treated group; \&P $<0.05$, \&\&\&P $<0.005$ between the compared groups (2-ways ANOVA followed by Bonferroni post-test)

flow $(\mathrm{P}<0.0001$ and $\mathrm{F}=37.1$, one-way ANOVA); the basal coronary flow value in the control test was $5.58 \pm$ $0.41 \mathrm{ml} / \mathrm{min}$ after perfusion with L-NAME $10 \mu \mathrm{M}$ for $30 \mathrm{~min}$. After $10 \mathrm{~min}$ treatment with vehicle, coronary flow did not significantly change $(5.45 \pm 0.37 \mathrm{ml} / \mathrm{min})$. Perfusion of 5-HT at concentrations of 0.3 and $1 \mu \mathrm{M}$ significantly increased coronary flow to $14.63 \pm 3.16 \mathrm{ml} /$ min and $14.58 \pm 2.13 \mathrm{ml} / \mathrm{min}$ (both $\mathrm{P}<0.001$ compared to the vehicle treatment), respectively. Treatment with quinacrine $1 \mu \mathrm{M}$ slightly increased coronary flow to $6.16 \pm 0.74 \mathrm{ml} / \mathrm{min}$ from $5.07 \pm 0.68 \mathrm{ml} / \mathrm{min}$; and after the treatment with quinacrine, 5 -HT induced slight coronary flow increases at $0.3 \mu \mathrm{M}(7.82 \pm 1.62 \mathrm{ml} / \mathrm{min})$ and $1 \mu \mathrm{M}(7.98 \pm 1.77 \mathrm{ml} / \mathrm{min})$. The values of coronary flow at 5 -HT 0.3 and $1 \mu \mathrm{M}$ in the presence of quinacrine were significantly lower than those in the control test (both $\mathrm{P}<$ 0.001 compared to the corresponding doses in the control test). Histamine $10 \mu \mathrm{M}$ increased the coronary flow to $10.31 \pm 1.61 \mathrm{ml} / \mathrm{min}$ at the end of the experiment.

As shown in Fig. 3b, 5-HT-induced coronary flow increases were significantly suppressed in the presence of
SKF525A $3 \mu \mathrm{M}(\mathrm{n}=7 ; \mathrm{P}=0.008$ and $\mathrm{F}=9.738,2$-ways ANOVA). 5-HT induced significant coronary flow increases in the control test $(\mathrm{P}<0.0001$ and $\mathrm{F}=50.89$, one-way ANOVA); basal value of the control test was $6.16 \pm 1.10 \mathrm{ml} / \mathrm{min}$, and treatment with vehicle did not significantly alter coronary flow $(6.25 \pm 1.26 \mathrm{ml} / \mathrm{min}) .5$ $\mathrm{HT}$ at concentrations 0.3 and $1 \mu \mathrm{M}$ increased coronary flow to $11.74 \pm 1.28(\mathrm{P}<0.01)$ and $12.68 \pm 1.50(\mathrm{P}<0.005)$ $\mathrm{ml} / \mathrm{min}$, respectively. Coronary flow was significantly altered after treatment of SKF525A $3 \mu \mathrm{M}$ and 5-HT $(\mathrm{P}<$ 0.0001 and $F=19.77$, one-way ANOVA). SKF525A $3 \mu \mathrm{M}$ increased coronary flow from the basal value of $5.60 \pm$ $1.02 \mathrm{ml} / \mathrm{min}$ to $8.37 \pm 0.54 \mathrm{ml} / \mathrm{min}(\mathrm{P}<0.005)$, which was proposed to be mediated by the release of $\mathrm{PGI}_{2}$ from endothelium [34]. In the presence of SKF525A, 5HT did not significantly alter coronary flow at concentrations 0.3 and $1 \mu \mathrm{M}(8.41 \pm 0.70$ and $8.33 \pm 0.95 \mathrm{ml} /$ min, respectively), and coronary flow after treatments of 5-HT 0.3 and $1 \mu \mathrm{M}$ were significantly lower than the corresponding values in the control test (both $\mathrm{P}<$ 0.005). Histamine $10 \mu \mathrm{M}$ increased coronary flow to 

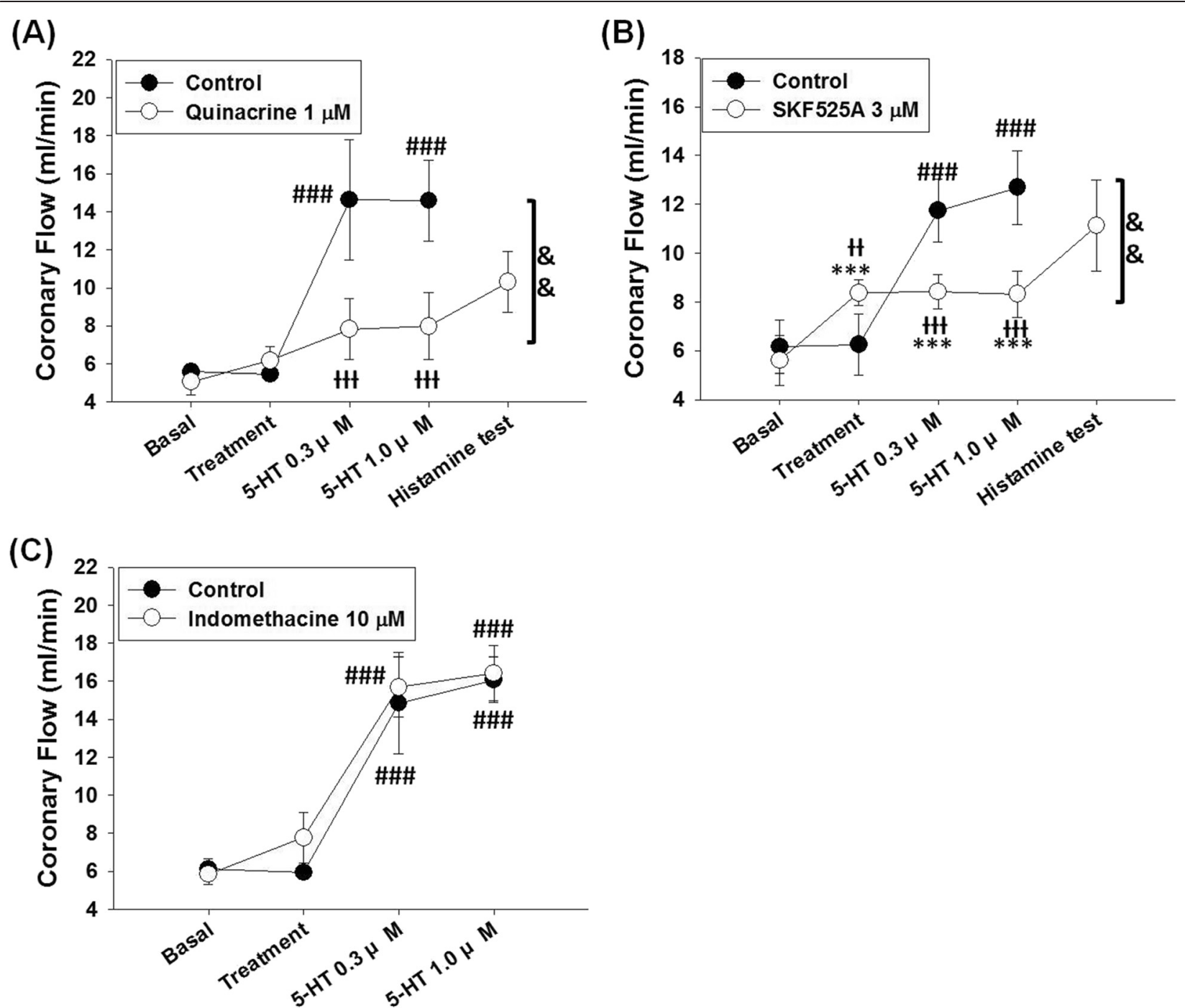

Fig. 3 Effects of the inhibitors of arachidonic acid metabolism on 5-HT-induced coronary response in L-NAME-treated hearts. a Treatment with the PLA 2 blocker quinacrine $1 \mu \mathrm{M}$ slightly increased coronary flow, and after treatment of quinacrine, 5-HT-induced coronary flow increases were suppressed. b Treatment with the cytochrome P450 inhibitor SKF525A $3 \mu \mathrm{M}$ significantly increased coronary flow, and in the presence of SKF525A, 5-HT-induced coronary flow increases were blocked. c Treatment of the COX inhibitor indomethacin $10 \mu \mathrm{M}$ did not significantly influence 5-HT-induced coronary flow increase. Data were expressed as the mean \pm SD. ${ }^{* *} \mathrm{P}<0.005$ compared to basal value; \#\#\#P $<0.005$ compared to the treatment. HP $<0.01$, HPP $<0.005$ compared to the control group (one-way ANOVA followed by Bonferroni post-test); \&\&P $<0.01$ between the compared groups ( 2 -ways ANOVA followed by Bonferroni post-test)

$11.13 \pm 1.85 \mathrm{ml} / \mathrm{min}$ in the histamine test at the end of experiment.

Treatment with indomethacin $10 \mu \mathrm{M}$ (Fig. 3c) did not significantly affect 5-HT-induced coronary flow increases in L-NAME-treated hearts $(\mathrm{n}=4 ; \mathrm{P}=0.3299$ and $\mathrm{F}=$ 0.09741, 2-ways ANOVA). 5-HT elicited significant increases of coronary flow in the control test $(\mathrm{n}=4 ; \mathrm{P}<$ 0.0001 and $F=39.81$, one-way ANOVA). Treatment with vehicle did not significantly increase the coronary flow (basal value $6.11 \pm 0.57 \mathrm{ml} / \mathrm{min}$ and the value after vehicle treatment $5.94 \pm 0.37 \mathrm{ml} / \mathrm{min}$ ) in the control test. 5 -HT increased coronary flow to $14.85 \pm 2.67$ and $16.08 \pm 1.19 \mathrm{ml} /$ min at concentrations $0.3 \mu \mathrm{M}$ and $1 \mu \mathrm{M}$ (both $\mathrm{P}<0.001$ compared to the vehicle treatment point), respectively. 5HT elicited coronary flow increases in the presence of indomethacin $10 \mu \mathrm{M}(\mathrm{P}<0.0001$ and $\mathrm{F}=64.01$, one-way ANOVA). Treatment with indomethacin slightly increased coronary flow to $7.78 \pm 1.32 \mathrm{~min} / \mathrm{ml}$ from the basal value of $5.84 \pm 0.52 \mathrm{ml} / \mathrm{min}$. In the presence of indomethacin, 5HT $0.3 \mu \mathrm{M}$ and $1 \mu \mathrm{M}$ increased the coronary flow to $15.65 \pm 0.79 \mathrm{ml} / \mathrm{min}$ and $16.56 \pm 0.73 \mathrm{ml} / \mathrm{min}$ (both $\mathrm{P}<$ 0.001 compared to corresponding points in the control test), respectively. Since the 5-HT-induced coronary flow responses were not significantly altered, we did 
not perform histamine test in this group at the end of the experiment.

\section{Effects of the $\mathrm{Ca}^{2+}$-activated $\mathrm{K}^{+}$channel blockers on} 5-HT-induced L-NAME-resistant coronary flow increases As shown in Fig. 4a, treatment of TRAM-34 $10 \mu \mathrm{M}$ significantly suppressed 5 -HT-induced coronary flow increases in L-NAME treated hearts $(\mathrm{n}=5 ; \mathrm{P}=0.0047$ and $\mathrm{F}=15.03$, 2-ways ANOVA). 5-HT elicited coronary flow increases in the control test $(\mathrm{P}<0.0001$ and $\mathrm{F}=21.42$, one-way ANOVA); treatment with vehicle (DMSO $100 \mu \mathrm{l} / \mathrm{dl}) \mathrm{did}$ not significantly alter coronary flow $(6.88 \pm 0.61 \mathrm{ml} / \mathrm{min}$ compared to the basal value $6.84 \pm 0.59 \mathrm{ml} / \mathrm{min}$ ) in the control test, and 5-HT 0.3 and $1 \mu \mathrm{M}$ increased coronary flow to $12.49 \pm 3.04 \mathrm{ml} / \mathrm{min}(\mathrm{P}<0.001$ compared to vehicle treatment) and $14.47 \pm 2.05 \mathrm{ml} / \mathrm{min}(\mathrm{P}<0.001$ compared to vehicle treatment), respectively. 5-HT failed to elicit coronary flow increases after treatment of TRAM-34 $10 \mu \mathrm{M}(\mathrm{P}=0.5857$ and $\mathrm{F}=0.6649$, oneway ANOVA). Treatment of TRAM-34 $10 \mu \mathrm{M}$ slightly decreased coronary flow to $5.20 \pm 1.59 \mathrm{ml} / \mathrm{min}$ from the basal value $(6.86 \pm 0.59 \mathrm{ml} / \mathrm{min})$. In the presence of TRAM-34, 5-HT did not significantly alter coronary flow at $0.3 \mu \mathrm{M}(6.99 \pm 3.09 \mathrm{ml} / \mathrm{min})$ or $1 \mu \mathrm{M}(6.38 \pm$
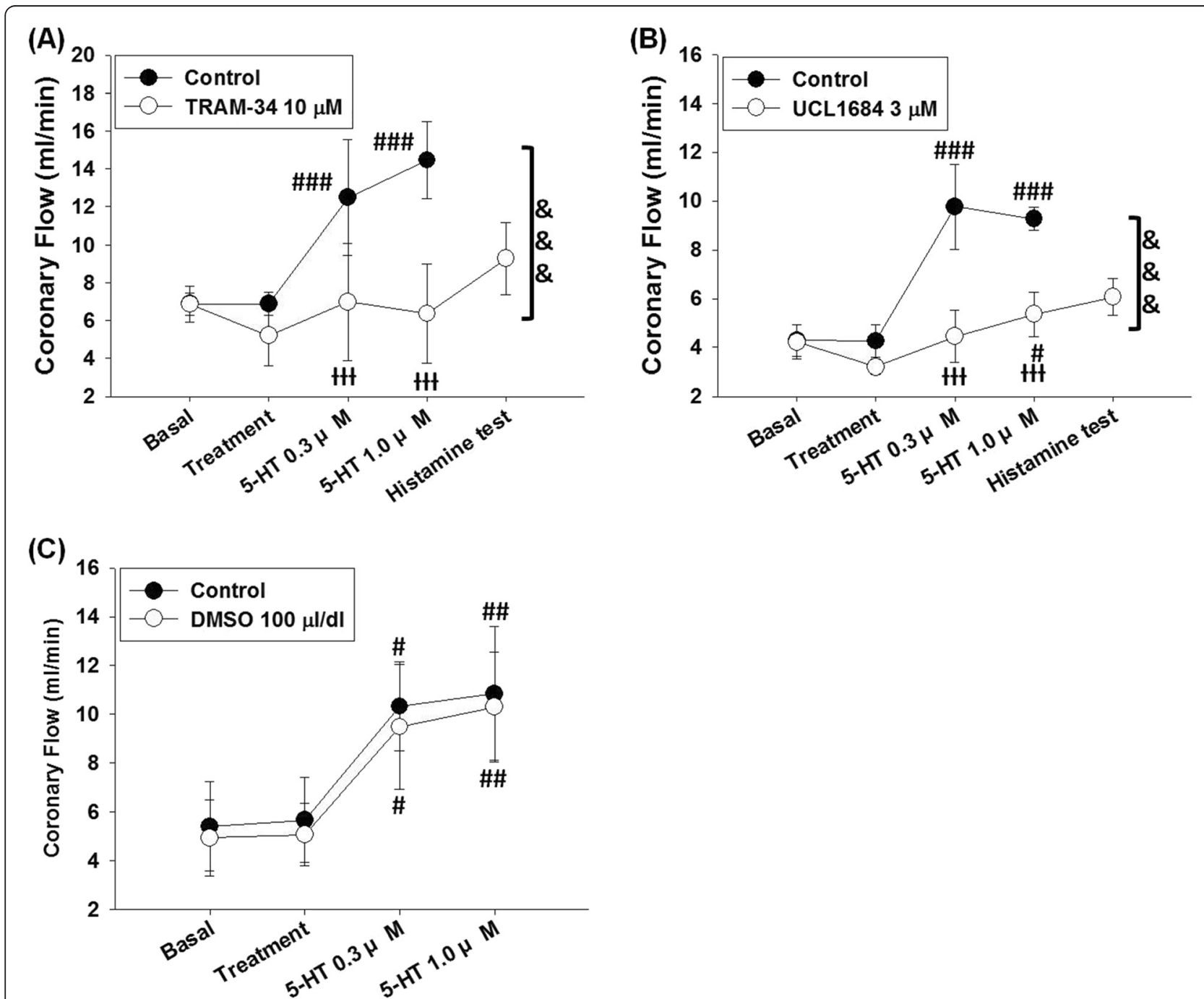

Fig. 4 Effects of small- and intermediate-conductance $\mathrm{Ca}^{2+}$-activated $\mathrm{K}^{+}$channel blockers on 5-HT-induced coronary response. In LNAME-treated hearts: a 5-HT-induced coronary flow increases were significantly suppressed by TRAM-34, which is a selective blocker of intermediate-conductance $\mathrm{Ca}^{2+}$-activated $\mathrm{K}^{+}$channel. $\mathbf{b}$ In hearts treated with the selective blocker of small-conductance $\mathrm{Ca}^{2+}$-activated $\mathrm{K}^{+}$channel UCL1684 $3 \mu \mathrm{M}, 5-\mathrm{HT}$ elicited slight coronary flow increase at $1 \mu \mathrm{M}$; but compared to the control test, 5-HT-induced coronary flow increases were significantly suppressed. c Coronary flow responses to 5-HT were not significantly altered after re-equilibration, prolonged perfusion with L-NAME, and repeated treatments of vehicle (DMSO $100 \mu \mathrm{l} / \mathrm{dl}$ ). Data were expressed as the mean \pm SD. \#P $<0.05$, \#\#P $<0.01$, and \#\#\# $<0.005$ compared to the treatment (one-ways ANOVA followed by Bonferroni post-test). HHP $<0.005$ compared to the control group; \&\&\&P $<0.001$ between the compared groups (2-ways ANOVA followed by Bonferroni post-test) 
$2.63 \mathrm{ml} / \mathrm{min}$ ). Coronary flow increased to $9.28 \pm 1.90 \mathrm{ml} /$ min in the histamine test at the end of experiment.

5-HT-induced coronary flow increases were significantly suppressed by UCL1684 $3 \mu \mathrm{M}(\mathrm{n}=4 ; \mathrm{P}=0.0036$ and $F=21.33$, 2-ways ANOVA) (Fig. 4b). In the control test, 5-HT induced significant coronary flow increases $(\mathrm{P}<0.0001$ and $\mathrm{F}=35.55$, one-way ANOVA). Treatment of vehicle (DMSO $30 \mu \mathrm{l} / \mathrm{dl}$ ) did not cause significant alteration of coronary flow $(5.66 \pm 1.74 \mathrm{ml} / \mathrm{min}$ compared to the basal value $5.41 \pm 1.82 \mathrm{ml} / \mathrm{min}$ ). Coronary flow increased to $10.32 \pm 1.82 \mathrm{ml} / \mathrm{min}$ and $10.84 \pm 2.75 \mathrm{ml} / \mathrm{min}$ after perfusion with $5-\mathrm{HT}$ at concentrations of 0.3 and $1 \mu \mathrm{M}$ (both $\mathrm{P}<0.001$ compared to the vehicle treatment point), respectively. In the presence of UCL1684, 5-HT elicited slight increases of coronary flow $(\mathrm{P}=0.0189$ and $\mathrm{F}=4.899$, one-way ANOVA). Treatment of UCL1684 $3 \mu \mathrm{M}$ slightly reduced the coronary flow from the basal value of $4.28 \pm 0.70 \mathrm{ml} / \mathrm{min}$ to $3.20 \pm 0.32 \mathrm{ml} / \mathrm{min}$. In the presence of UCL1684 treatment, 5-HT slightly increased coronary flow to $4.46 \pm 1.08 \mathrm{ml} / \mathrm{min}$ at $0.3 \mu \mathrm{M}$, and 5HT increased coronary flow to $5.37 \pm 0.92 \mathrm{ml} / \mathrm{min}$ at $1 \mu \mathrm{M} \quad(\mathrm{P}<0.05$ compared to the ULC1684 treatment point). The values of coronary flow at 5-HT 0.3 and $1 \mu \mathrm{M}$ in the presence of UCL1684 are lower than the corresponding values in the control test (both $\mathrm{P}<0.001$ ). At the end of the experiment, addition of histamine $10 \mu \mathrm{M}$ increased coronary flow to $6.07 \pm 0.77 \mathrm{ml} / \mathrm{min}$ in the presence of UCL1684 and 5-HT.

As shown in Fig. 4c, repeated treatments of DMSO $100 \mu \mathrm{l} / \mathrm{dl}$ did not significantly alter 5 -HT-induced coronary flow responses $(\mathrm{n}=5 ; \mathrm{P}=0.6122$ and $\mathrm{F}=0.2782$, 2-ways ANOVA). In the control test, 5-HT elicited coronary flow increases in the presence of DMSO $100 \mu \mathrm{l} /$ $\mathrm{dl}(\mathrm{P}=0.0006$ and $\mathrm{F}=9.938$, one-way ANOVA $)$. The basal value of coronary flow was $5.41 \pm 1.82 \mathrm{ml} / \mathrm{min}$, and perfusion with DMSO $100 \mu \mathrm{l} / \mathrm{dl}$ for $15 \mathrm{~min}$ did not significantly alter coronary flow $(5.66 \pm 1.74 \mathrm{ml} / \mathrm{min})$ in the control test. In the presence of DMSO $100 \mu \mathrm{l} / \mathrm{dl}$, perfusion with 5 - $\mathrm{HT}$ at concentrations of 0.3 and $1 \mu \mathrm{M}$ increased coronary flow to $10.32 \pm 1.82 \mathrm{ml} / \mathrm{min} \quad(\mathrm{P}<0.05$ compared to the vehicle treatment point) and $10.84 \pm$ $2.75 \mathrm{ml} / \mathrm{min}(\mathrm{P}<0.01$ compared to the vehicle treatment point), respectively. In the second test, 5 -HT still elicited coronary flow increases $(P=0.0005$ and $F=10.28$, oneway ANOVA). Perfusion with DMSO $100 \mu \mathrm{l} / \mathrm{dl}$, as in the control test, did not significantly alter coronary flow (5.06 $\pm 1.28 \mathrm{ml} / \mathrm{min}$ compared to basal value $4.93 \pm 1.57 \mathrm{ml} /$ $\mathrm{min}) ; 5$-HT increased coronary flow to $9.48 \pm 2.57$ at $0.3 \mu \mathrm{M}$ and to $10.30 \pm 2.24 \mathrm{ml} / \mathrm{min}$ at $1 \mu \mathrm{M}(\mathrm{P}<0.05$ and $\mathrm{P}<0.01$ compared to DMSO $100 \mu \mathrm{l} / \mathrm{dl}$ treatment, respectively) in the presence of DMSO $100 \mu \mathrm{l} / \mathrm{ml}$.

Treatment of penitrem A $1 \mu \mathrm{M}$ did not significantly altered 5-HT-induced coronary flow increases in LNAME treated hearts $(\mathrm{n}=7 ; \mathrm{P}=0.5661$ and $\mathrm{F}=0.3481$, 2-ways ANOVA) (Fig. 5a). 5-HT elicited coronary flow increases in the control test $(\mathrm{P}<0.0001$ and $\mathrm{F}=31.79$, one-way ANOVA). Perfusion with vehicle (DMSO $10 \mu \mathrm{l} /$ dl) for $15 \mathrm{~min}$ did not significantly alter coronary flow $(5.39 \pm 0.62 \mathrm{ml} / \mathrm{min}$ compared to basal value $5.40 \pm$ $0.43 \mathrm{ml} / \mathrm{min}$ ); in the presence of vehicle, 5 -HT increased coronary flow to $9.84 \pm 2.11 \mathrm{ml} / \mathrm{min}$ at $0.3 \mu \mathrm{M}$ and $10.09 \pm 1.05 \mathrm{ml} / \mathrm{min}$ at $1 \mu \mathrm{M}$ (both $\mathrm{P}<0.005$ compared to the vehicle treatment). 5 -HT could still elicit coronary flow increases after treatment of penitrem A $1 \mu \mathrm{M}(\mathrm{P}<$ 0.0001 and $F=13.48$, one-way ANOVA). The basal coronary flow after $20 \mathrm{~min}$ re-equilibration was $5.36 \pm$ $0.72 \mathrm{ml} / \mathrm{min}$, and perfusion with penitrem A $1 \mu \mathrm{M}$ for $15 \mathrm{~min}$ did not significantly alter coronary flow (6.16 \pm $1.26 \mathrm{ml} / \mathrm{min}$ ). In the presence of penitrem A, 5- $\mathrm{HT}$ at concentrations of 0.3 and $1 \mu \mathrm{M}$ increased coronary flow to $10.25 \pm 2.70$ and $10.49 \pm 2.35 \mathrm{ml} / \mathrm{min}$, respectively (both $\mathrm{P}<0.01$ compared to penitrem A treatment). Since coronary flow responses to 5 -HT were not significantly diminished by penitrem $\mathrm{A}$, we did not perform histamine test at the end of experiment.

5-HT-induced coronary flow responses in L-NAME treated hearts did not significantly alter in the presence of paxilline $2 \mu \mathrm{M}$ (Fig. 5b). In the control test, 5 -HT induced significant coronary flow increases in the presence of vehicle $(\mathrm{n}=5 ; \mathrm{P}<0.0001$ and $\mathrm{F}=45.88$, one-way ANOVA). Treatment of vehicle (DMSO $10 \mu \mathrm{l} / \mathrm{dl}$ ) did not significant alter coronary flow $(6.79 \pm 0.82 \mathrm{ml} / \mathrm{min}$ compared to the basal value $6.84 \pm 1.14 \mathrm{ml} / \mathrm{min}$ ); coronary flow increased to $15.29 \pm 1.06$ and $13.39 \pm 2.32 \mathrm{ml} / \mathrm{min}$ after treatments of 5-HT $0.3 \mu \mathrm{M}$ and $1 \mu \mathrm{M}$, respectively (both $\mathrm{P}<0.001$ compared to the vehicle treatment). Treatment of paxilline $2 \mu \mathrm{M}$ slightly increased coronary flow to $8.45 \pm$ $1.75 \mathrm{ml} / \mathrm{min}$ from the basal value $7.13 \pm 1.03 \mathrm{ml} / \mathrm{min}$; in the presence of paxilline $2 \mu \mathrm{M}, 5-\mathrm{HT}$ induced coronary flow increases to $14.94 \pm 3.16 \mathrm{ml} / \mathrm{min}$ at $0.3 \mu \mathrm{M}$ and $13.60 \pm 2.79 \mathrm{ml} / \mathrm{min}$ at $1 \mu \mathrm{M}(\mathrm{P}<0.01$ and $\mathrm{P}<0.05$ compared to treatment of paxilline $2 \mu \mathrm{M}$, respectively).

As shown in Fig. 5c, treatment of TEA $300 \mu \mathrm{M}$ significantly suppressed 5-HT-induced coronary flow increases $(\mathrm{n}=5 ; \mathrm{P}=0.0014$ and $\mathrm{F}=22.67,2$-ways ANOVA). In the control test, 5-HT induced significant coronary flow increases $(\mathrm{P}<0.0001$ and $\mathrm{F}=24.79$, one-way ANOVA); the basal value of coronary flow was $5.03 \pm 0.48 \mathrm{ml} / \mathrm{min}$, and coronary flow after $15 \mathrm{~min}$ of prolonged perfusion was $4.78 \pm 0.51 \mathrm{ml} / \mathrm{min}$. 5-HT induced coronary flow increases to $9.32 \pm 1.59 \mathrm{ml} / \mathrm{min}$ at $0.3 \mu \mathrm{M}$ and $9.01 \pm$ $1.37 \mathrm{ml} / \mathrm{min}$ at $1 \mu \mathrm{M}$ (both $\mathrm{P}<0.001$ compared to the vehicle treatment point). 5-HT-induced coronary flow increase responses at 0.3 and $1 \mu \mathrm{M}$ were suppressed in the presence of TEA $300 \mu \mathrm{M}(\mathrm{P}=0.0632$ and $\mathrm{F}=2.970$, one-way ANOVA). The basal coronary flow after reequilibration was $4.28 \pm 0.46 \mathrm{ml} / \mathrm{min}$. After perfusion with TEA $300 \mu \mathrm{M}$ for $15 \mathrm{~min}$, coronary flow was $4.29 \pm$ 

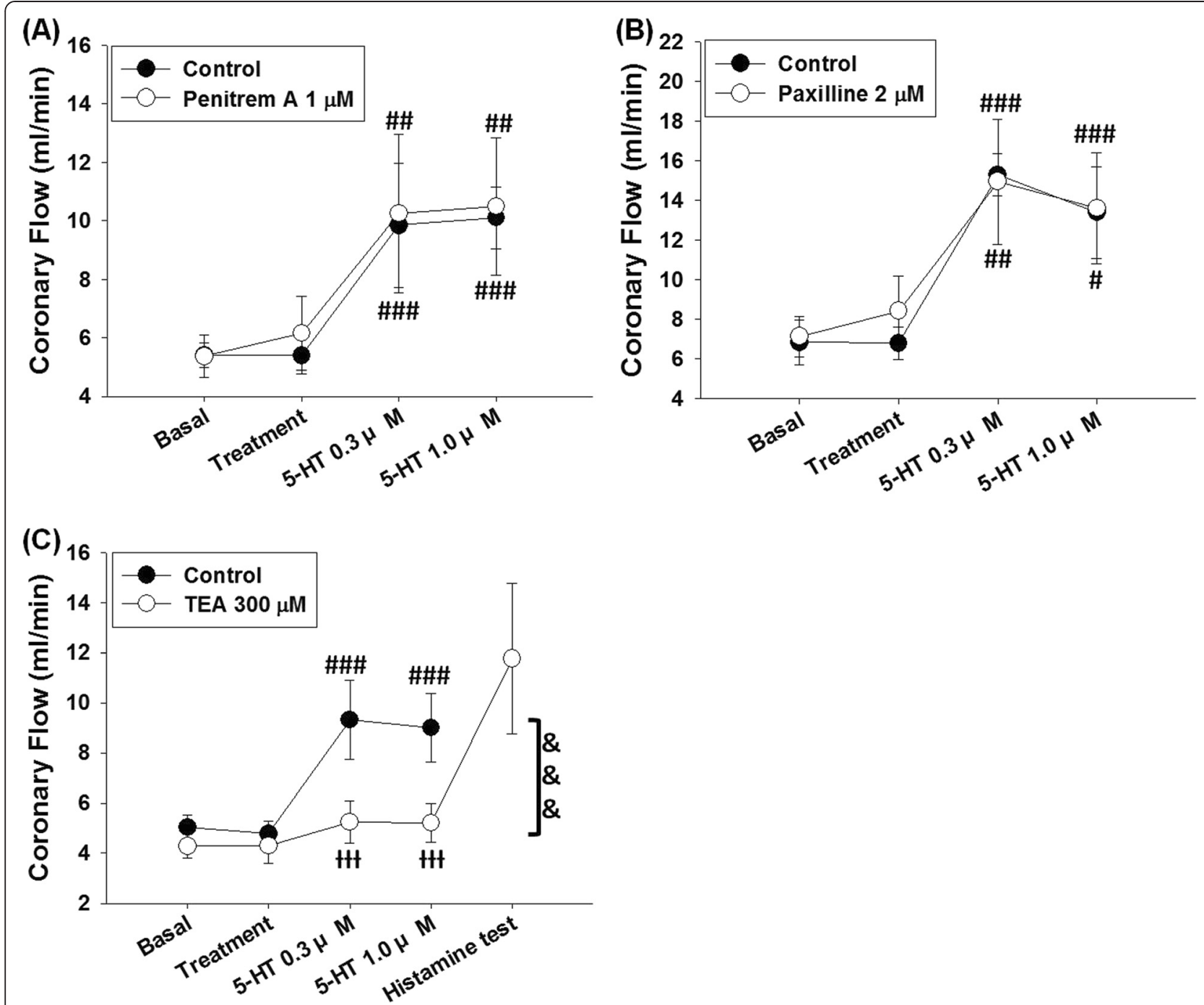

Fig. 5 Effects of the large-conductance $\mathrm{Ca}^{2+}$-activated $\mathrm{K}^{+}$channel blockers on 5-HT-induced coronary responses in L-NAME-treated hearts. a 5-HT-induced coronary flow increases were not significantly affected by penitrem A $1 \mu \mathrm{M}$. b Treatment of paxilline $2 \mu \mathrm{M}$ did not significantly alter 5-HT-induced coronary flow increases. c 5-HT-induced coronary flow increases were significantly suppressed by treatment with TEA $300 \mu \mathrm{M}$. Data were expressed as the mean \pm $\mathrm{SD}$. \#P $<0.05$, \#\#P $<0.01$, \#\#\# < 0.005 compared to the treatment (one-ways ANOVA followed by Bonferroni post-test). $\mathrm{WIP}<0.005$ compared to control group; \&\&\&P $<0.005$ between the compared groups (2-ways ANOVA followed by Bonferroni post-test)

$0.68 \mathrm{ml} / \mathrm{min}$. In the presence of TEA, 5-HT failed to cause significant coronary flow increases at $0.3(5.24 \pm$ $0.83 \mathrm{ml} / \mathrm{min})$ and $1 \mu \mathrm{M}(5.20 \pm 0.78 \mathrm{ml} / \mathrm{min})$. Histamine increased coronary flow to $11.76 \pm 3.01 \mathrm{ml} / \mathrm{min}$ in the histamine test at the end of the experiment.

\section{Discussion}

The vasorelaxation effect of 5-HT on human coronary arteries has been identified for more than 20 years [1, 2], but this property of 5-HT has not been addressed as much as the vasoconstrictive effect. 5-HT-induced coronary artery dilation has been reported to be NO-dependent in many species $[13,35,36]$; however, the 5-HT-induced coronary flow increases are, at least partially, resistant to
L-NAME in rats [9]. In the present study, we investigated the role of $5-\mathrm{HT}_{7}$ receptor in 5-HT-induced coronary flow increases in isolated rat hearts in the absence of L-NAME. As shown in Fig. 2b and c, both 5-HT and the selective 5$\mathrm{HT}_{7}$ receptor agonist 5-CT [24] induced coronary flow increases in the absence of L-NAME, and both of these effects were blocked by $0.3 \mu$ M SB269970, which is a potent and selective $5-\mathrm{HT}_{7}$ receptor antagonist (Ki value $1.26 \mathrm{nM}$ [21]); furthermore, 5-HT turned to decrease coronary flow in the presence of SB269970, and this effect was blocked by the selective $5-\mathrm{HT}_{2 \mathrm{~A}}$ receptor antagonist $\mathrm{R} 965440.3 \mu \mathrm{M}$ (Fig. 2b). It is noteworthy that SB269970 blocked 5-CTinduced coronary flow increases, but 5-CT, which has very low affinity to $5-\mathrm{HT}_{2 \mathrm{~A}}$ receptor (Ki value $633-2700 \mathrm{nM}$ ) 
[24], did not cause coronary flow decrease in the presence of SB269970 (Fig. 2c). These results indicate that the coronary flow-decreasing component of 5-HT-induced coronary flow responses is mediated by $5-\mathrm{HT}_{2 \mathrm{~A}}$ receptor, which is in consensus with previous reports [37, 38], and both NO-dependent $[11,12,38]$ and L-NAME-resistant [9] components of coronary flow increases induced by $5-\mathrm{HT}$ at doses of 0.3 and $1 \mu \mathrm{M}$ are mediated by the activation of $5-\mathrm{HT}_{7}$ receptor.

Endothelium is an important apparatus in vascular tissues, and damage or malfunction of endothelium causes poor regulation of vascular responses. Endothelium helps regulate vessel tone by releasing vasoconstrictive agents [39] and vasodilating factors. $\mathrm{NO}$ [13], $\mathrm{PGI}_{2}$ [26], and EDHF [17] are the main dilating factors released from endothelium. NO induces an increase of cGMP in smooth muscle cells and then causes smooth muscle relaxation [40, 41]. $\mathrm{PGI}_{2}$ is a metabolite of COX [42]; it activates $\mathrm{PGI}_{2}$ receptors on smooth muscle cells, and then causes vasodilation by increasing intracellular cAMP [43]. $\mathrm{PGI}_{2}$ has been reported to mediate 5 -HT-induced coronary vascular resistance reduce in rat hearts [14], but in the present study we did not find role of COX metabolites in 5-HT-induced coronary flow increases in L-NAME-treated hearts (Fig. 3b).

EDHF elicits vasodilation by inducing hyperpolarization of membrane potentials, which consequently prevents the opening of $\mathrm{Ca}^{2+}$ channels and hence reduces $\mathrm{Ca}^{2+}$ influx [17]. So far, there is no consensus on what the entity of EDHF is, and the exact mechanism(s) of how EDHF induces vasodilation remains controversial [18]; but the involvements of $\mathrm{K}^{+}$ion and $\mathrm{Ca}^{2+}$-activated $\mathrm{K}^{+}$channels in EDHF-induced vasorelaxation are commonly recognized [16]. Several models describing how $\mathrm{Ca}^{2+}$-activated $\mathrm{K}^{+}$channels and $\mathrm{K}^{+}$ion induce smooth muscle relaxation have been proposed [16-18]: One model suggests that the activation of $\mathrm{Ca}^{2+}$-activated $\mathrm{K}^{+}$ channel(s) on endothelium leads to $\mathrm{K}^{+}$ion efflux, and the efflux of $\mathrm{K}^{+}$ion causes membrane potential hyperpolarization of the endothelial cells, which then results in the membrane potential hyperpolarization of smooth muscle cells via gap junctions connecting the endothelium cells and the smooth muscle cells [44, 45]. In evidences for a second model, the released $\mathrm{K}^{+}$ion from endothelium cells via $\mathrm{Ca}^{2+}$-activated $\mathrm{K}^{+}$channel(s) increases local concentration of $\mathrm{K}^{+}$ion in the intercellular space between the endothelium and the smooth muscle [46]; the elevated concentration of extracellular $\mathrm{K}^{+}$in the loci causes the activation of inward rectified $\mathrm{K}^{+}$channels or/and $\mathrm{Na}^{+} / \mathrm{K}$ ${ }^{+}$pump on the smooth muscle cells [17] and hence induces the hyperpolarization of membrane potentials, which consequently prevents the vessels from constriction.

All 3 types of $\mathrm{Ca}^{2+}$-activated $\mathrm{K}^{+}$channels have been reported involved in the EDHF-mediated vasorelaxation. For example, $\mathrm{H}_{2} \mathrm{O}_{2}$, one of the supposed EDHFs [47], is released from the endothelium in response to shear force and then causes dilation of human coronary arterioles by activating large-conductance $\mathrm{Ca}^{2+}$-activated $\mathrm{K}^{+}$ channel on the smooth muscle cells [48]. Small- and intermediate-conductance $\mathrm{Ca}^{2+}$-activated $\mathrm{K}^{+}$channels, both of which can be activated by the arachidonic acid metabolites synthesized by cytochrome P450s and 15LOX [18], have been reported mediating acetylcholineinduced vasodilation on coronary arterioles derived from normal rats [49], while large-conductance $\mathrm{Ca}^{2+}$-activated $\mathrm{K}^{+}$channel plays no role in this response; this finding also implies that all these 3 types of $\mathrm{Ca}^{2+}$-activated $\mathrm{K}^{+}$ channels are not necessarily involved in an EDHFmediated vasorelaxation at the same time.

Arachidonic acid metabolites-induced activation of $\mathrm{Ca}^{2+}$-activated $\mathrm{K}^{+}$channels has been reported involved in EDHF-mediated vasorelaxation $[15,25]$. In the present study, we investigated the role of EDHF in 5HT-induced coronary flow increases by using pharmacological tools that interfere with the $\mathrm{PLA}_{2}$ - cytochrome P450 - $\mathrm{Ca}^{2+}$-activated $\mathrm{K}^{+}$channel axis [18]. As shown in Fig. 3a-c, the inhibitions of PLA 2 by quinacrine $[15,25]$ and cytochrome P450s by SKF525A [25] significantly suppressed 5-HT-induced coronary flow increases while the inhibition of COX by indomethacin [26] failed to influence the 5-HT-induced responses; these results indicate the involvement of the cytochrome P450s-synthesized arachidonic acid metabolites rather than $\mathrm{PGI}_{2}[14]$ in 5-HT-induced coronary flow increases in L-NAMEtreated hearts. And as shown in Fig. 4a and b, blocking intermediate- and small-conductance $\mathrm{Ca}^{2+}$-activated $\mathrm{K}^{+}$ channels with TRAM-34 [30] and UCL1684 [31] significantly inhibited 5-HT-induced coronary flow increases in L-NAME-treated hearts. These results are in consensus with previous reports that epoxyeicosatrienoic acid isomers activate intermediate- and small-conductance $\mathrm{Ca}^{2+}$-activated $\mathrm{K}^{+}$channels in EDHF-induced relaxation of the vascular tissues $[18,50,51]$.

Activation of large-conductance $\mathrm{Ca}^{2+}$-activated $\mathrm{K}^{+}$channel mediates vasorelaxation in various vascular tissues. For example, applications of BMS191011 and NS1619, both of which are openers of large-conductance $\mathrm{Ca}^{2+}$-activated $\mathrm{K}^{+}$ channel [52, 53], elicit vasodilation of isolated perfused sheep coronary arteries with $\mathrm{pD} 2$ (the negative logarithm to base 10 of the $\mathrm{EC}_{50}$ ) of $5.76 \pm 0.4$ and $5.86 \pm 0.5$, respectively [54]; in mice, large-conductance $\mathrm{Ca}^{2+}$-activated $\mathrm{K}^{+}$channel is involved in acetylcholine-elicited NO-independent vasorelaxation on isolated skeletal muscle arterioles from diet-induced obese mice, although largeconductance $\mathrm{Ca}^{2+}$-activation $\mathrm{K}^{+}$channel blocker does not affect the acetylcholine-induced response on the skeletal muscle arterioles from normal mice [49].

In the present study, the results are diverse in the experiments using the blockers to verify the role of large- 
conductance $\mathrm{Ca}^{2+}$-activated $\mathrm{K}^{+}$channel in 5-HT-induced coronary flow increases in L-NAME-treated hearts (Fig. 5). Paxilline [33] and penitrem A [32] are both selective and potent large-conductance $\mathrm{Ca}^{2+}$-activated $\mathrm{K}^{+}$channel blockers; TEA, the other blocker of large-conductance $\mathrm{Ca}^{2+}$-activated $\mathrm{K}^{+}$channel we used, is generally used as non-selective $\mathrm{K}^{+}$channels blocker [55], but at doses lower than $1 \mathrm{mM}$ it is selective to large-conductance $\mathrm{Ca}^{2+}$-activated $\mathrm{K}^{+}$channel [55]. As shown in Fig. 5a-c, paxilline $2 \mu \mathrm{M}$ and penitrem A $1 \mu \mathrm{M}$ failed to inhibit 5HT-induced coronary flow increases in L-NAME treated hearts; however, 5-HT-induced coronary flow increases were blocked by TEA $300 \mu \mathrm{M}$. It is an interesting finding because in previous reports paxilline $0.2 \mu \mathrm{M}$ is as potent as TEA $1 \mathrm{mM}$ in blocking iberiotoxin-sensitive $\mathrm{K}^{+}$current in isolated rat aorta smooth muscle cells [56], and in the smooth muscle cells isolated from rat vas deferens, paxilline $1 \mu \mathrm{M}$ completely blocks large-conductance $\mathrm{Ca}^{2+}$-activated $\mathrm{K}^{+}$channel current, which effect is similar to TEA $0.3 \mathrm{mM}$ [57].

Penitrem A is a potent and selective large-conductance $\mathrm{Ca}^{2+}$-activated $\mathrm{K}^{+}$channel blocker with $\mathrm{IC}_{50}$ of $6.40 \mathrm{nM}$ [32], and it has been used to investigate the role of largeconductance $\mathrm{Ca}^{2+}$-activated $\mathrm{K}^{+}$channel in vasorelaxation in several studies $[32,58,59]$. In porcine coronary endothelial cells, penitrem A $10 \mathrm{nM}$ completely blocks the hyperpolarization elicited by $10 \mu \mathrm{M} 1$-EB10, a selective opener of large-conductance $\mathrm{Ca}^{2+}$-activated $\mathrm{K}^{+}$channel [60], and partially inhibits the membrane potential hyperpolarization elicited by the adenosine receptor agonist 5 'ethylcarboxamidoadenosine $10 \mu \mathrm{M}$ [61]; in portal vein smooth muscle cells from rats, treatment of penitrem 100 nM completely blocks the hyperpolarization elicited by NS1619 $33 \mu \mathrm{M}$ [53]. Paxilline is a potent and selective blocker of large-conductance $\mathrm{Ca}^{2+}$-activated $\mathrm{K}^{+}$channel with Ki value $1.9 \mathrm{nM}$ [33]. In rat isolated aortic smooth muscle cells, paxilline $1 \mu \mathrm{M}$ almost completely blocks iberiotoxin-sensitive current with $\mathrm{IC}_{50}$ of $97 \mathrm{nM}$, while TEA blocks the iberiotoxin-sensitive current with $\mathrm{IC}_{50}$ of $273 \mu \mathrm{M}$ [56]; in rat mesenteric arterial cells, paxilline completely blocks iberiotoxin-sensitive current at $300 \mathrm{nM}$ [62]; in the isolated human coronary arterioles, paxilline $0.1 \mu \mathrm{M}$ significantly inhibits $\mathrm{H}_{2} \mathrm{O}_{2}$-elicited vasodilation [48]. Judging from these studies, the failures of paxilline and penitrem A in inhibiting 5-HT-induced coronary flow increases in L-NAME treated hearts do not come from that the concentrations we used are not high enough since the doses we used in the present study (paxilline $2 \mu \mathrm{M}$ and penitrem $\mathrm{A} 1 \mu \mathrm{M}$ ) are much higher than those in the aforementioned studies. Besides, according to our unpublished observation, the opener of large-conductance $\mathrm{Ca}^{2+}$-activated $\mathrm{K}^{+}$channel BMS191610 does not elicit coronary flow increase at 3 and $10 \mu \mathrm{M}$ in L-NAME-treated hearts (data not shown), both of which doses are higher than the $\mathrm{EC}_{50}$ of BMS191610 in inducing vasorelaxation of isolated normal fetal sheep coronary arteries in previous study [54].

Although evidences from paxilline and penitrem A do not support the involvement of large-conductance $\mathrm{Ca}^{2+}$-activated $\mathrm{K}^{+}$channel in 5-HT-induced coronary flow increases in L-NAME treated hearts, coronary flowincreasing effect of 5-HT was suppressed by TEA (Fig. 5). As mentioned above, TEA is a widely used non-selective antagonist of various $\mathrm{K}^{+}$channels, including 3 types of $\mathrm{Ca}^{2+}$-activated $\mathrm{K}^{+}$channels, voltage-dependent $\mathrm{K}^{+}$channel, ATP-sensitive $\mathrm{K}^{+}$channel, and inward rectified $\mathrm{K}^{+}$channels [55]. The suppressing effect of TEA on 5-HTinduced coronary flow increases in L-NAME-treated hearts did not likely come from blocking small- and/or intermediate-conductance $\mathrm{Ca}^{2+}$-activated $\mathrm{K}^{+}$channels, because at doses lower than $1 \mathrm{mM}$ TEA is selective to largeconductance $\mathrm{Ca}^{2+}$-activated $\mathrm{K}^{+}$channel [63], and in our preliminary tests TEA $0.3 \mathrm{mM}$ does not have significant effect on the coronary flow increases induced by SKA-31, a selective opener of small- and intermediate-conductance $\mathrm{Ca}^{2+}$-activated $\mathrm{K}^{+}$channels [30], in L-NAME treated hearts (data not shown).

The evidences we mentioned above suggest that the difference between effects of TEA and the other two blockers on 5-HT-induced coronary flow increases does not likely come from failures of paxilline and peintrem A in blocking large-conductance $\mathrm{Ca}^{2+}$-activated $\mathrm{K}^{+}$channel, but unfortunately we do not know what is the origin of the difference so far. The role of large-conductance $\mathrm{Ca}^{2+}$-activated $\mathrm{K}^{+}$channel and/or the TEA-sensitive component in 5HT-induced coronary flow increases in L-NAME treated hearts need further investigation.

\section{Conclusion}

In conclusion, the activation of $5-\mathrm{HT}_{7}$ receptor mediates 5-HT-induced coronary flow increases in isolated hearts in the absence of L-NAME as in L-NAMEtreated hearts as previously reported [9]. The coronary flow-increasing effect of 5-HT in L-NAME-treated hearts resemble the characters of EDHF-induced vasorelaxation: the inhibitors of $\mathrm{PLA}_{2}$ and cytochrome P450s, but not the inhibitor of COX, block 5-HT-induced coronary flow increases in L-NAME treated hearts, and smalland intermediate-conductance $\mathrm{Ca}^{2+}$-activated $\mathrm{K}^{+}$channels are also involved in the 5-HT-induced coronary flow responses in L-NAME treated hearts. However, the role of large-conductance $\mathrm{Ca}^{2+}$-activated $\mathrm{K}^{+}$channel in 5 -HT-induced coronary flow increases needs further investigation.

To the best of our knowledge, the present study is the first to investigate the role of EDHF in 5-HT-induced vasorelaxation on the coronary arteries. 


\section{Abbreviations}

5-CT: 5-carboxamidotryptamine; 5-HT: 5-hydroxytryptamine; COX: Cyclooxygenase; DMSO: Dimethyl sulfoxide; EC50: Half maximal effective concentration; EDHF: Endothelium derived hyperpolarizing factor; IC50: Half maximal inhibitory concentration; L-NAME: N $\omega$-Nitro-L-arginine methyl ester hydrochloride; LOX: Lipoxygenase; NO: Nitric oxide; NOS: Nitric oxide synthase; $\mathrm{pD}_{2}$ : Negative logarithm to base 10 of the $\mathrm{EC}_{50}$.

\section{Competing interests}

The authors declare that they have no competing interests.

\section{Authors' contributions}

C-C C C: The experiments and analyses of the data in the present study were carried out by this author, and he was also involved in the design of the study and drafting of the manuscript. M-J S: Prof. Su was the supervisor of the present study. He was involved in the design of the study, and he was also involved in the drafting and revising of the present manuscript. Both authors read and approved the final manuscripts.

\section{Acknowledgement}

The source of financial support: This work was supported by National Science Council, Taiwan (NSC 102-2325-B-002-056, NSC 100-2325-B-002-008, NSC 101-2325-B-002-010, NSC 102-2325-B-002-095-B4, and MOST-103-2325-B002-020). The National Science Council did not intervene with the design and practice of experiments proposed in this article; neither did they have any command on the data interpretation or writing in this article.

\section{Received: 13 January 2015 Accepted: 19 May 2015}

\section{Published online: 16 June 2015}

\section{References}

1. McFadden EP, Clarke JG, Davies GJ, Kaski JC, Haider AW, Maseri A. Effect of intracoronary serotonin on coronary vessels in patients with stable angina and patients with variant angina. N Engl J Med. 1991;324:648-54.

2. Golino P, Piscione F, Willerson JT, Cappelli-Bigazzi M, Focaccio A, Villari B, et al. Divergent effects of serotonin on coronary-artery dimensions and blood flow in patients with coronary atherosclerosis and control patients. N Engl J Med. 1991;324:641-8.

3. McFadden EP, Bauters C, Lablanche JM, Leroy F, Clarke JG, Henry M, et al. Effect of ketanserin on proximal and distal coronary constrictor responses to intracoronary infusion of serotonin in patients with stable angina, patients with variant angina, and control patients. Circulation. 1992;86:187-95.

4. Nilsson T, Longmore J, Shaw D, Pantev E, Bard JA, Branchek T, et al. Characterisation of 5-HT receptors in human coronary arteries by molecular and pharmacological techniques. Eur J Pharmacol. 1999;372:49-56.

5. Eglen RM, Jasper JR, Chang DJ, Martin GR. The 5-HT7 receptor: orphan found. Trends Pharmacol Sci. 1997:18:104-7.

6. Bard JA, Zgombick J, Adham N, Vaysse P, Branchek TA, Weinshank RL. Cloning of a novel human serotonin receptor (5-HT7) positively linked to adenylate cyclase. J Biol Chem. 1993;268:23422-6.

7. Lenglet S, Louiset E, Delarue C, Vaudry H, Contesse V. Involvement of T-type calcium channels in the mechanism of action of 5-HT in rat glomerulosa cells: a novel signaling pathway for the 5-HT7 receptor. Endocr Res. 2002;28:651-5.

8. Terron JA. The relaxant 5-HT receptor in the dog coronary artery smooth muscle: pharmacological resemblance to the cloned 5-ht7 receptor subtype. Br J Pharmacol. 1996;118:1421-8.

9. Chang Chien CC, Hsin LW, Su MJ. Activation of serotonin 5-HT(7) receptor induces coronary flow increase in isolated rat heart. Eur J Pharmacol. 2015;748:68-75.

10. Martorana PA, Goebel B, Ruetten H, Koehl D, Keil M. Coronary endothelial dysfunction after ischemia and reperfusion in the dog: a functional and morphological investigation. Basic Res Cardiol. 1998;93:257-63.

11. Bouchard JF, Chouinard J, Lamontagne D. Participation of prostaglandin E2 in the endothelial protective effect of ischaemic preconditioning in isolated rat heart. Cardiovasc Res. 2000;45:418-27.

12. Joyeux M, Bouchard JF, Lamontagne D, Godin-Ribuot D, Ribuot C. Heat stress-induced protection of endothelial function against ischaemic injury is abolished by ATP-sensitive potassium channel blockade in the isolated rat heart. Br J Pharmacol. 2000;130:345-50.
13. Mankad PS, Chester AH, Yacoub MH. 5-Hydroxytryptamine mediates endothelium dependent coronary vasodilatation in the isolated rat heart by the release of nitric oxide. Cardiovasc Res. 1991;25:244-8.

14. Gereliuk IP, Stukal IK. The mechanisms of the effect of serotonin on the prostacyclin synthesis and coronary vascular resistance of the isolated rat heart. Fiziologicheskii zhurnal SSSR imeni I M Sechenova. 1992;78:55-60.

15. Hecker M, Bara AT, Bauersachs J, Busse R. Characterization of endotheliumderived hyperpolarizing factor as a cytochrome P450-derived arachidonic acid metabolite in mammals. J Physiol. 1994;481(Pt 2):407-14.

16. Grgic I, Kaistha BP, Hoyer J, Kohler R. Endothelial Ca + -activated K+ channels in normal and impaired EDHF-dilator responses-relevance to cardiovascular pathologies and drug discovery. Br J Pharmacol. 2009;157:509-26.

17. Garland CJ, Hiley CR, Dora KA. EDHF: spreading the influence of the endothelium. Br J Pharmacol. 2011;164:839-52.

18. Campbell WB, Gauthier KM. Inducible endothelium-derived hyperpolarizing factor: role of the 15-lipoxygenase-EDHF pathway. J Cardiovasc Pharmacol. 2013;61:176-87.

19. Fisslthaler B, Popp R, Kiss L, Potente M, Harder DR, Fleming I, et al. Cytochrome P450 2C is an EDHF synthase in coronary arteries. Nature. 1999;401:493-7.

20. Fleming I. Cytochrome P450 epoxygenases as EDHF synthase(s). Pharmacol Res. 2004;49:525-33.

21. Lovell PJ, Bromidge SM, Dabbs S, Duckworth DM, Forbes IT, Jennings AJ, et al. A novel, potent, and selective 5-HT(7) antagonist: (R)-3-(2-(2-(4-methylpiperidin-1-yl) ethyl)pyrrolidine-1-sulfonyl) phen ol (SB-269970). J Med Chem. 2000;43:342-5.

22. Ogawa T, Sugidachi A, Tanaka N, Fujimoto K, Asai F. Pharmacological profiles of R-96544, the active form of a novel 5-HT2A receptor antagonist R-102444. Eur J Pharmacol. 2002;457:107-14.

23. Hinschen AK, Rose'Meyer RB, Headrick JP. Age-related changes in adenosine-mediated relaxation of coronary and aortic smooth muscle. Am J Physiol Heart Circulatory Physiol. 2001;280:H2380-9.

24. Zifa E, Fillion G. 5-Hydroxytryptamine receptors. Pharmacol Rev. 1992;44:401-58.

25. Bauersachs J, Hecker M, Busse R. Display of the characteristics of endotheliumderived hyperpolarizing factor by a cytochrome P450-derived arachidonic acid metabolite in the coronary microcirculation. Br J Pharmacol. 1994;113:1548-53.

26. Gwozdz P, Drelicharz L, Kozlovski Vl, Chlopicki S. Prostacyclin, but not nitric oxide, is the major mediator of acetylcholine-induced vasodilatation in the isolated mouse heart. Pharmacol Reports. 2007;59:545-52.

27. Harrison GJ, Jordan LR, Willis RJ. Deleterious effects of hydrogen peroxide on the function and ultrastructure of cardiac muscle and the coronary vasculature of perfused rat hearts. Can J Cardiol. 1994;10:843-9.

28. Harrison GJ, Jordan LR, Selley ML, Willis RJ. Low-density lipoproteins inhibit histamine and $\mathrm{NaNO} 2$ relaxations of the coronary vasculature and reduce contractile function in isolated rat hearts. Heart Vessel. 1995;10:249-57.

29. Van de Voorde J, Brochez V, Vanheel B. Heterogenous effects of histamine on isolated rat coronary arteries. Eur J Pharmacol. 1994;271:17-23.

30. Mishra RC, Belke D, Wulff H, Braun AP. SKA-31, a novel activator of SK(Ca) and $\mathrm{IK}(\mathrm{Ca})$ channels, increases coronary flow in male and female rat hearts. Cardiovasc Res. 2013;97:339-48.

31. Dunn PM. UCL 1684: a potent blocker of $\mathrm{Ca} 2+-$ activated $\mathrm{K}+$ channels in rat adrenal chromaffin cells in culture. Eur J Pharmacol. 1999;368:119-23.

32. Asano S, Bratz IN, Berwick ZC, Fancher IS, Tune JD, Dick GM. Penitrem A as a tool for understanding the role of large conductance $\mathrm{Ca}(2+) /$ voltage-sensitive $\mathrm{K}(+)$ channels in vascular function. J Pharmacol Exp Ther. 2012;342:453-60.

33. Sanchez M, McManus OB. Paxilline inhibition of the alpha-subunit of the high-conductance calcium-activated potassium channel. Neuropharmacology. 1996;35:963-8.

34. Rees DD, Palmer RM, Moncada S. Effect of SKF 525A on the release of nitric oxide and prostacyclin from endothelial cells. Eur J Pharmacol. 1988;150:149-54

35. Cocks TM, Angus JA. Endothelium-dependent relaxation of coronary arteries by noradrenaline and serotonin. Nature. 1983;305:627-30.

36. Ellwood AJ, Curtis MJ. Involvement of 5-HT(1B/1D) and 5-HT2A receptors in 5-HT-induced contraction of endothelium-denuded rabbit epicardial coronary arteries. Br J Pharmacol. 1997;122:875-84.

37. Saxena PR, Villalon CM. Cardiovascular effects of serotonin agonists and antagonists. J Cardiovasc Pharmacol. 1990;15 Suppl 7:S17-34.

38. Lai FM, Tanikella T, Cervoni P. Characterization of serotonin receptors in isolated rat intramyocardial coronary artery. J Pharmacol Exp Ther. 1991;256:164-8. 
39. Maguire JJ, Davenport AP. PD156707: a potent antagonist of endothelin-1 in human diseased coronary arteries and vein grafts. J Cardiovasc Pharmacol. 1998;31 Suppl 1:S239-40.

40. Conti V, Russomanno G, Corbi G, Izzo V, Vecchione C, Filippelli A. Adrenoreceptors and nitric oxide in the cardiovascular system. Front Physiol. 2013;4:321.

41. Gielen S, Sandri M, Erbs S, Adams V. Exercise-induced modulation of endothelial nitric oxide production. Curr Pharm Biotechnol. 2011;12:1375-84

42. Zeldin DC. Epoxygenase pathways of arachidonic acid metabolism. J Biol Chem. 2001:276:36059-62.

43. Kukovetz WR, Holzmann S, Wurm A, Poch G. Prostacyclin increases CAMP in coronary arteries. J Cyclic Nucleotide Res. 1979:5:469-76.

44. Yamamoto Y, Imaeda K, Suzuki H. Endothelium-dependent hyperpolarization and intercellular electrical coupling in guinea-pig mesenteric arterioles. J Physiol. 1999;514(Pt 2):505-13.

45. Edwards G, Feletou M, Gardener MJ, Thollon C, Vanhoutte PM, Weston AH. Role of gap junctions in the responses to EDHF in rat and guinea-pig small arteries. Br J Pharmacol. 1999;128:1788-94.

46. Edwards G, Dora KA, Gardener MJ, Garland CJ, Weston AH. K+ is an endothelium-derived hyperpolarizing factor in rat arteries. Nature. 1998:396:269-72

47. Shimokawa H. Hydrogen peroxide as an endothelium-derived hyperpolarizing factor. Pflugers Arch - Eur J Physiol. 2010;459:915-22

48. Liu Y, Bubolz AH, Mendoza S, Zhang DX, Gutterman DD. H2O2 is the transferrable factor mediating flow-induced dilation in human coronary arterioles. Circ Res. 2011;108:566-73.

49. Feher A, Rutkai I, Beleznai T, Ungvari Z, Csiszar A, Edes I, et al. Caveolin-1 limits the contribution of $\mathrm{BK}(\mathrm{Ca})$ channel to EDHF-mediated arteriolar dilation: implications in diet-induced obesity. Cardiovasc Res. 2010;87:732-9.

50. Moroe $\mathrm{H}, \mathrm{Honda} \mathrm{H}$. Comparison of endothelial function in the carotid artery between normal and short-term hypercholesterolemic rabbits. Comp Biochem Physiol Toxicol Pharmacol. 2006;144:197-203.

51. Dong H, Waldron GJ, Galipeau D, Cole WC, Triggle CR. NO/PGI2-independent vasorelaxation and the cytochrome $\mathrm{P} 450$ pathway in rabbit carotid artery. $\mathrm{Br}$ J Pharmacol. 1997;120:695-701.

52. Mori A, Suzuki S, Sakamoto K, Nakahara T, Ishii K. BMS-191011, an opener of large-conductance $\mathrm{Ca} 2+$-activated potassium channels, dilates rat retinal arterioles in vivo. Biol Pharm Bull. 2011:34:150-2.

53. Edwards G, Niederste-Hollenberg A, Schneider J, Noack T, Weston AH. Ion channel modulation by NS 1619, the putative BKCa channel opener, in vascular smooth muscle. Br J Pharmacol. 1994;113:1538-47.

54. Shukla P, Ghatta S, Dubey N, Lemley CO, Johnson ML, Modgil A, et al. Maternal nutrient restriction during pregnancy impairs an endotheliumderived hyperpolarizing factor-like pathway in sheep fetal coronary arteries. Am J Physiol Heart Circ Physiol. 2014;307:H134-42.

55. Nelson MT, Quayle JM. Physiological roles and properties of potassium channels in arterial smooth muscle. Am J Physiol. 1995;268:C799-822.

56. Tammaro P, Smith AL, Hutchings SR, Smirnov SV. Pharmacological evidence for a key role of voltage-gated $\mathrm{K}+$ channels in the function of rat aortic smooth muscle cells. Br J Pharmacol. 2004;143:303-17.

57. Kryshtal DO, Nesin W, Shuba MF, Kryshtal DO, Nesin W, Shuba MF. Effect of paxilline on $\mathrm{Ca}(2+)$-dependent $\mathrm{K}+$ current in smooth muscle cells isolated from rat vas deferens. Fiziolohichnyi zhurnal (Kiev, Ukraine : 1994). 2007:53:67-74

58. Asano S, Tune JD, Dick GM. Bisphenol A activates Maxi-K (K(Ca)1.1) channels in coronary smooth muscle. Br J Pharmacol. 2010;160:160-70.

59. Borbouse L, Dick GM, Payne GA, Payne BD, Svendsen MC, Neeb ZP, et al. Contribution of BK(Ca) channels to local metabolic coronary vasodilation: Effects of metabolic syndrome. Am J Physiol Heart Circ Physiol. 2010:298:H966-73.

60. Adeagbo AS. 1-Ethyl-2-benzimidazolinone stimulates endothelial K(Ca) channels and nitric oxide formation in rat mesenteric vessels. Eur J Pharmacol. 1999;379:151-9.

61. Olanrewaju HA, Gafurov BS, Lieberman EM. Involvement of K+ channels in adenosine $A 2 A$ and $A 2 B$ receptor-mediated hyperpolarization of porcine coronary artery endothelial cells. J Cardiovasc Pharmacol. 2002:40:43-9.

62. Li G, Cheung DW. Effects of paxilline on $\mathrm{K}+$ channels in rat mesenteric arterial cells. Eur J Pharmacol. 1999:372:103-7.

63. Lang DG, Ritchie AK. Tetraethylammonium blockade of apamin-sensitive and insensitive Ca2(+)-activated $\mathrm{K}+$ channels in a pituitary cell line. J Physiol. 1990:425:117-32.

\section{Submit your next manuscript to BioMed Central and take full advantage of:}

- Convenient online submission

- Thorough peer review

- No space constraints or color figure charges

- Immediate publication on acceptance

- Inclusion in PubMed, CAS, Scopus and Google Scholar

- Research which is freely available for redistribution

Submit your manuscript at www.biomedcentral.com/submit

C Biomed Central 